\title{
Buffer strip management to deliver plant and invertebrate resources for farmland birds in agricultural landscapes
}

WESTBURY, D.B. ${ }^{1^{*}}$, WOODCOCK, B.A. ${ }^{2}$, HARRIS, S.J. ${ }^{3}$, BROWN, V.K. ${ }^{3}$ \& POTTS, S.G. ${ }^{3}$

${ }^{1}$ Institute of Science \& the Environment, University of Worcester, Henwick Grove, Worcester, WR2 6AJ, UK.

${ }^{2}$ Centre for Ecology \& Hydrology, Maclean Building, Wallingford, Oxfordshire OX10 8BB, UK

${ }^{3}$ Centre for Agri-Environmental Research, School of Agriculture, Policy \& Development, University of Reading, PO Box 237, Earley Gate, Reading, RG6 6AR, UK.

*Corresponding author: Tel: + 44 (0) 1905 542461; E-mail: d.westbury@worc.ac.uk

Total Word Count $=7,517$

Key words: Agri-environment; Field margins; Sward structure; Coleoptera; beetles; Cutting; Scarification; Graminicide. 


\section{Abstract}

To address the decline in farmland birds across agricultural landscapes a key approach under agri-environment schemes has been the widespread creation of perennial grass-only buffer strips along field boundaries. However, despite a high dependency on these strips to enhance biodiversity in agricultural landscapes, it appears that benefits for farmland birds during the breeding season have been limited. We investigated the provision of plant and invertebrate resources for farmland birds in buffer strips that were established with three different seed mixes, including the standard grass-only habitat. We hypothesised that resource provision would differ between seed mix types due to differences in original composition. We also investigated three different types of management aimed at influencing sward composition and habitat structure, namely cutting, scarification and the application of graminicide. These approaches were used to influence the accessibility of structurally complex swards to farmland birds. We hypothesised that the abundance of plant and invertebrate resources and access to these resources would be directly related to management type. The abundance of plant resources and sward structure were determined using quadrats and the drop disc method respectively, whilst the invertebrates were assessed using suction sampling. The study demonstrated the value of including forbs (herbaceous plant species) in seed mixes used to establish buffer strips by increasing plant resources for farmland birds, although this was not coupled with an increase in beetle abundance and mass. However, grass-only buffer strips managed with annual cutting were shown to provide similar levels of invertebrate resources to farmland birds as with the more complex seed mixes, but it is likely that access to these resources was restricted by tall homogenous swards and a limited amount of bare ground. The study demonstrated that novel buffer strip management techniques can strongly influence both the resource abundance and resource access by farmland birds. Scarification in particular was shown to be highly effective at opening up the sward to increase access by farmland birds, but was associated with a reduction in plant resources. Given the financial barriers for the use of seed mixes that contain forbs to establish buffer strips, importantly the study has shown that the value of existing grass-only buffer strips for farmland birds can be enhanced through the use of scarification. Consequently, as an alternative to annual cutting, we recommend that scarification is periodically applied to narrow (1-3 m) strips next to the crop edge to enhance the value of grass-only buffer strips for farmland birds.

\section{Introduction}


Throughout Europe substantial declines in farmland birds have occurred since the 1970's (Fuller et al., 1995; Donald et al., 2001) due to agricultural intensification. In the UK, this led to an extensive research programme to investigate the ecological requirements of priority bird species (Peach et al., 2001; Peach et al., 2004; Butler et al., 2010), and culminated with the development of a farmland bird package (Winspear et al., 2010). This package advocates the creation of new habitat and the appropriate management of cropped areas to provide essential resources for birds, including seed and invertebrate prey. Through the delivery of UK agri-environment schemes several red listed bird species have benefitted from the adoption of these approaches, primarily due to an increase in winter food resources (Baker et al., 2012). However, options aimed at providing resources during the breeding season have had either mixed or very limited benefits (Baker et al., 2012). A key approach has been the widespread creation of perennial grass-only buffer strips along field boundaries (Critchley et al., 2006; Vickery et al., 2009), which can support a range of other taxa including invertebrates (Field et al., 2005; Woodcock et al., 2005; Merckx et al., 2009), reptiles (Biaggini and Corti, 2015), and small mammals (Aschwanden et al., 2007; Broughton et al., 2014). However, these buffer strips have had limited benefits for farmland birds during the breeding season (Baker et al., 2012). In fact, the presence of buffer strips in arable fields have been linked with negative population growth rates of corn bunting (Emberiza calandra), goldfinch (Carduelis carduelis) and yellow wagtail (Motacilla flava) (Baker et al., 2012). This is despite corn bunting preferring to establish territories in arable fields containing buffer strips (Burgess et al., 2015) and goldfinches regularly foraging in buffer strip vegetation (Vickery and Fuller, 1998).

In England there is an estimated 30,000 ha of perennial grass buffer strip habitat that has been established either by sowing grass-only seed mixtures, or by a process of natural regeneration (Harold Makant, Natural England, personal communication, 2016). These simple and basic approaches have been driven by the lack of farmer incentives to sow floristically-rich seed mixes and the lower cost of grass-only seed mixes. The association between plant diversity and the abundance and diversity of higher trophic levels is well documented (Woodcock and Pywell, 2010), and whilst grass-only buffer strips will provide additional resources for birds (Vickery et al., 2009), their widespread adoption across agricultural landscapes is unlikely to have resulted in large gains in invertebrate resources that support bird populations. To address the issue of current measures not delivering benefits for farmland birds during the breeding season (Baker et al., 2012) there is clearly a need to investigate how grass-only buffer strips can be managed to enhance benefits for farmland birds. Furthermore, if floristically-rich buffers strips are to be advocated, there is 
also a need to investigate how this type of habitat can be managed to maximise benefits for farmland birds.

In addition to the availability of resources within newly created habitats, a further factor limiting use by many farmland birds is the extent to which the physical structure of the sward makes those resources accessible (Vickery et al., 2001; Atkinson et al., 2005). A number of studies have investigated the management of grass leys and pastures to increase access for farmland birds (Vickery et al., 2001; Vickery et al., 2004; Atkinson et al., 2005; Whittingham and Devereux, 2008), but in contrast, there has been very limited research on the management of grass buffer strips to increase resource provision and access. In an effort to enhance the value of grass-only buffer strips for yellowhammers (Emberiza citrinella), Douglas et al. (2009) investigated the influence of cutting to create and maintain short, open patches of vegetation throughout the breeding season. It was found that foraging by yellowhammers increased significantly between early and late summer due to greater access to invertebrates, especially beetles. Beetles (Coleoptera) are highly important in the diets of farmland birds during the breeding season (Wilson et al., 1999) and as a consequence, the management of buffer strips to increase the abundance and accessibility of this resource is likely to be of benefit.

We investigated the provision of plant and invertebrate resources for farmland birds in buffer strips established with three different seed mixes, including the standard grass-only seed mix that represents the lowest cost option typically used by farmers. We hypothesised that resource provision would differ between seed mix type due to differences in original composition. As access to resources, rather than food abundance per se could be the critical factor in determining habitat use by farmland birds (Atkinson et al., 2005), we also investigated three different types of management aimed at influencing sward composition and therefore habitat structure. We hypothesised that the abundance of plant and invertebrate resources and access to these resources would be directly related to management type.

\section{Methods}

\subsection{Experimental design}

At three UK sites, non-cropped perennial arable buffer strips were established on clay

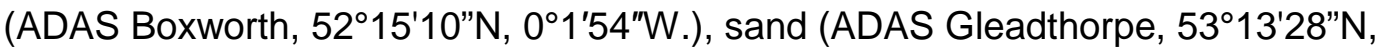




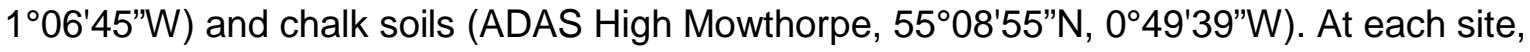
five replicate blocks consisting of nine experimental plots measuring $25 \mathrm{~m} \times 5 \mathrm{~m}$ were established along hedgerow field boundaries, with three different seed mixtures. Individual plots were separated by $5 \mathrm{~m}$ buffers. In each of the five blocks, three randomly selected plots were sown with a grass-only (GO) seed mixture, three with a tussock grass and forb (herbaceous plant species) mixture (TG), and three with a fine grass and forb mixture (FG) (see Appendix for species lists). The sowing rates for the mixes were 20.0, 35.1 and $36.2 \mathrm{~kg}$ $\mathrm{ha}^{-1}$, respectively and plots were sown once only. The different forb-based seed mixes (TG and FG) contained species including Centaurea nigra and Silene dioica that are important in the diets of a range of farmland birds (Holland et al., 2006). The seed mixes were selected to provide a contrast in plant community composition and vegetation structure, and are frequently used for habitat creation. Boxworth and High Mowthorpe were both sown in autumn 2001, whilst due to inundation, Gleadthorpe was sown in spring 2002. During the establishment year (2002) all plots were cut in late summer with a tractor-mounted flail cutter to a height of approximately $15 \mathrm{~cm}$ and cuttings were left in situ.

From 2003, the management treatments of cutting, sward scarification and selective graminicide were applied annually in March/April for a period of four years to each of the three seed mixtures. This created a randomised three by three factorial design within each replicate block. The treatments were selected to directly benefit farmland birds by influencing the composition and sward structure of the different plant communities, and therefore access to resources. Treatments were applied in spring rather than late summer to increase the impact of treatments during the breeding season. Cutting is the standard technique for managing perennial buffer strips, and swards were cut to a height of $15 \mathrm{~cm}$ using a flail cutter and cuttings were left in situ. This approach was compared to the novel treatments of sward scarification and the application of graminicide as these have greater potential to increase plant species diversity (Westbury and Dunnett, 2008) and enhance access to resources. Scarification was applied using a power harrow to create approximately $60 \%$ soil disturbance by cultivating the top $2.5 \mathrm{~cm}$. For the graminicide treatment the chemical fluazifop-P-butyl (Fusilade Max ${ }^{\mathrm{TM}}$, Syngenta Crop Protection Ltd) was applied using a tractor-mounted sprayer at half the label rate $(0.8 \mathrm{~L}$ of product ha-1), in a volume rate of 200 $\mathrm{L} \mathrm{ha}^{-1}$. This is equivalent to $100 \mathrm{~g}$ active ingredient ha ${ }^{-1}$. The reduced application rate was to suppress, rather than eliminate susceptible grass species (Westbury and Dunnett, 2008). To improve the efficacy of the sward scarification and graminicide treatments, plots were cut to a height of approximately $30 \mathrm{~cm}$ with a flail cutter 2 - 3 weeks prior to application. Management of the cropped area adjacent to the buffer strips was based on a four-year crop 
rotation, which commenced with three years of winter wheat, followed by either potatoes, winter oil seed rape, or field beans.

\subsection{Assessments of plant resources}

Botanical assessments were performed in June $(2003,2004$, and 2006) in each plot using a $50 \mathrm{~cm} \times 50 \mathrm{~cm}\left(0.25 \mathrm{~m}^{2}\right)$ quadrat. Ten replicate quadrats were randomly positioned within each plot, leaving a buffer of approximately one metre around each plot to take into account edge effects. All vascular plant species were identified and assigned a percentage cover value (non-repetitive cover by vertical projection) according to an eight-point scale ( $1=<$ $1 \%, 2=1-5 \%, 3=6-10 \%, 4=11-20 \%, 5=21-40 \%, 6=41-60 \%, 7=61-80 \% \& 8=81-$ 100\%). Plant nomenclature follows (Stace, 2010).

In each quadrat, the proportion of plants that were reproductive was assigned a value according to a four-point scale $(1=1-25 \%, 2=26-50 \%, 3=51-75 \%, 4=76-100 \%)$. Plants were classed as being reproductive if they possessed buds, or flowers and/or seed/fruit that was forming, ripe or dehiscent. This approach provides an indirect measure of potential food abundance for granivorous and omnivorous birds across the season, whilst enabling a full determination of plant composition (Westbury et al., 2011). Plant species were selected for inclusion if considered important in the diets of granivorous farmland birds in the UK (Wilson et al., 1996; Marshall et al., 2003; Holland et al., 2006). An indicative value of resource abundance was calculated for each species by multiplying the proportion of plants that were observed to be reproductive, by the percentage cover value for that species in each quadrat. This provided a Plant Resource Index (PRI) value for each species. For each replicate plot, an average PRI value was then calculated according to four different plant categories namely, sown grasses, unsown grasses, sown forbs, and unsown forbs. Total PRI values were also calculated. The different categories were chosen to enable the relative contribution of sown forbs and grasses to be compared to those provided by species naturally occurring (unsown) in the buffer strips. However, it was also important to determine the effect of the management treatment on unsown forb and grass resources for farmland birds as these "weed" species also contribute to farmland bird diets (Wilson, 2001). Differentiating between grasses and forbs was also important because seed preference also varies according to bird species, with some (e.g. buntings) preferring carbohydrate-rich seed typical of plants in the Gramineae family, whilst others (sparrows and finches) prefer oil-rich seeds typical of numerous forb species, including those in the Asteraceae and Polygonaceae plant families (Perkins et al., 2007). By investigating the underlying 
components of plant resources, such an approach provides a greater understanding to the value of the different seed mixes and how buffer strip vegetation responds to management.

\subsection{Assessments of sward structure and accessibility}

To determine the spatial heterogeneity of vegetation within plots with respect to sward surface height, the drop disc method was used (Stewart et al., 2001). In June (2003, 2004, and 2006) a total of 24 measurements were taken from each replicate plot, sampling in a diagonal line with approximately one metre between each measurement. The drop disc was of standard weight $(200 \mathrm{~g})$ and diameter $(30 \mathrm{~cm})$. The disc covers an area of $707 \mathrm{~cm}^{2}$ and therefore provides an indication of leaf and stem density within the sward canopy. For each replicate plot the coefficient of variation $(\mathrm{CV})$ was calculated to provide a measure of sward heterogeneity; important with regards to the opportunity for farmland birds to access vegetation (Buckingham and Peach, 2006). Values of bare ground were obtained from the same quadrats used to determine plant community composition. Absolute values of bare ground were recorded as a percentage and were based on vertical projection prior to the disturbance of vegetation for botanical assessment. A total of 10 values were recorded for each replicate plot.

\subsection{Assessments of beetle abundance and mass}

The focus on beetles as a surrogate for invertebrate resources for farmland birds was due to their importance in the diets of farmland birds (Wilson et al., 1999), whilst being excellent indicators for the wider abundance of other invertebrates (e.g. Bohac, 1999). In 2003, 2004 and 2006, a Vortis suction sampler (Burkard Ltd., UK) was used to sample beetle assemblages within each replicate plot. Suction sampling was selected because it is widely used to investigate relationships between sward structure and the abundance and accessibility of invertebrate resources for farmland birds (e.g. Douglas et al., 2009). A total of $75 \times 10$ s suction samples were taken from each plot in both June and September, equating to sampling from a total fixed area of $2.90 \mathrm{~m}^{2}$ each year. Samples from each plot were pooled and summed according to year to provide one value for each replicate plot for each year of study. Sampling was undertaken between $10.00 \mathrm{~h}$ and $16.00 \mathrm{~h}$ and only when vegetation was dry. Beetles (Coleoptera) of the Carabidae, Chrysomelidae, Curculionoidea, Coccinellidae and Staphylinidae were all identified to species except for the Aleocharinae subfamily of the Staphylinidae. Values of mass (dry weight) were determined using the length to mass correlation (Rogers et al., 1976). This relationship has been widely used as a basis for determining the mass of insect communities (Saint-Germain et al. 2007, Woodcock 
et al. 2009), as it provides a high level of explanatory power $\left(\mathrm{R}^{2}=0.97\right.$, Rogers et al 1976). Such an approach is also highly practical as there is no need to remove plant litter inadvertently collected during sampling, before taking measurements.

\subsection{Statistical analysis}

For analyses of plant and invertebrate resources, seed mix type (GO, TG, and FG), management treatment (Cutting, Scarification, and Graminicide), and year, including the interactions between all these factors were set as fixed effects in a mixed linear model in SAS Studio (Version 3.5, 2016). The subject 'year' was also specified as a repeated measure with an autoregressive covariance structure. Site, and block nested within site, were specified as random effects. Degrees of freedom were calculated using the iterative Satterthwaite's method (Schabenberger and Pierce, 2002). Model simplification was performed by sequentially deleting interactions and then factors which were not significant $(P$ $>0.05$ ), unless part of significant interaction term. When a factor was significant and not part of a significant interaction, Tukey $(P=0.05)$ post-hoc pairwise comparisons were made to investigate underlying differences. Prior to analyses, values of plant and invertebrate resources were log transformed. The same model and approach was used to investigate the response of sward height, coefficient of variation of sward height, and values of bare ground. This enables resource provision and bird access according to seed mix type and sward treatment to be inferred.

\section{Results}

\subsection{Plant resource index (PRI) values}

\subsubsection{Total plant resources}

Total PRI values were strongly influenced by seed mix type and management treatment (Table 1). Values (log transformed) were significantly greater with cutting $(3.7 \pm 0.1)$ and graminicide (3.7 \pm 0.1 ), compared to scarification (3.3 \pm 0.1 ). Values were also significantly greater in plots sown with the FG mix, although a significant interaction between year and seed mix type (Table 1) indicated that responses were not consistent with time (Figure 1a).

\subsubsection{Sown plant resources}

Overall, PRI values of sown forbs were consistently greater in plots sown with seed mixes containing forbs, with the FG mix consistently providing a greater resource. However, the significant interaction between seed mix type and year (Table 1) indicates that responses 
were not consistent (Figure 1b). There were also significant interactions between seed mix type and management treatment for PRI values of sown forbs and grasses. In plots sown with the FG and TG seed mixes, sown forb PRI values were lower in association with scarification compared to cutting and graminicide, whilst GO plots treated with scarification or graminicide tended to have higher rather than lower contributions of sown forbs (Figure 1c). Irrespective of seed mix, the application of graminicide tended to increase values relative to cutting. The interaction between seed mix and management for the sown grasses (Figure 1d) indicated a tendency for a greater contribution of sown grasses in plots treated with cutting. The significant year effect on sown grass PRI values also indicated greater contributions in 2003 compared to subsequent years, with no difference between 2004 and 2006.

\subsubsection{Unsown plant resources}

Plots sown with the GO seed mix contained significantly greater unsown forb and unsown grass PRI values compared to the TG and FG mixes. Unsown forb PRI values (log+1 transformed) in the GO plots were $1.5( \pm 0.1)$, compared to $0.9( \pm 0.1)$ and $1.2( \pm 0.1)$ in the TG and FG plots respectively. Values of unsown forbs were also significantly greater in FG plots compared to the TG plots (Tukey, $P<0.05)$. Values of unsown grass PRI $(\log +1$ transformed) were $0.9( \pm 0.1)$ in the GO plots compared to $0.5( \pm 0.1)$ and $0.7( \pm 0.1)$ in the TG and FG plots respectively, and there was no significant difference between TG and FG plots (Tukey, $P>0.05$ ). A significant interaction between management and year was found for unsown forb PRI values (Table 1). Cutting was consistently associated with lower values across all years, whilst values in plots treated with either scarification or graminicide were similar, apart from in 2004, when values were greater in association with scarification (Figure 2). Management treatment also had significant impacts on values of unsown grasses (Table 1). Plots treated with graminicide had an average PRI value (log+1 transformed) of 0.4 $( \pm 0.1)$, which was significantly lower than plots treated with cutting $(0.7 \pm 0.1)$ or scarification $(1.0 \pm 0.1)$ (Tukey, $P<0.05)$. PRI values associated with scarification were significantly higher than with cutting (Tukey, $P<0.05$ ). The influence of year on unsown grass PRI values followed a similar pattern to the sown grass component, with significantly greater values in 2003 compared to 2004 and 2006.

\subsection{Invertebrate resources}

The influence of seed mix type on total beetle abundance was significant (Table 2), with greater values in plots sown with the TG mix, compared with the FG mix; values did not differ significantly between the TG and GO mixes, or between the GO and FG mix (Figure 
3). Seed mix type also had a significant impact on values of total beetle mass, with a tendency for values to be greater in plots sown with the TG mix, although the Tukey multiple comparison test did not detect a significant difference between mixes. Total beetle abundance and summed mass were not influenced by management treatment (Table 2), although a significant interaction between treatment and year was found for total beetle abundance. In 2003, total beetle abundance was greater in plots treated with either scarification or graminicide compared to cutting. However, in 2004 and 2006, values tended to be greater in plots managed solely with cutting (Figure 4). Total beetle mass was also strongly influenced by time, with significantly lower values (Tukey, $P<0.05)$ in $2003(4.96 \mathrm{mg}$ \pm 0.04 ), compared to 2004 (5.35 $\mathrm{mg} \pm 0.04)$ and 2006 (5.41 $\mathrm{mg} \pm 0.04)$.

\subsection{Vegetation structure and resource accessibility}

Seed mix type had a significant influence on values of mean sward height (Table 3), although this factor also interacted significantly with management treatment. Values were consistently lower with scarification across all seed mix types, although the application of graminicide to plots sown with the GO mix had a similar impact on sward height as with scarification (Figure 5). In plots sown with the TG and FG mixes, cutting and the application of graminicide were associated with similar values of sward height. Mean sward height and the coefficient of variation (CV) of height were significantly lower in 2004 compared to 2003 and 2006 (Table 3). CV values were also strongly influenced by sward treatment (Table 3), with significantly greater values associated with scarification (Figure 6), which was also coupled with greater values of bare ground (Figure 7). Swards managed with scarification were therefore more open, consisting of vegetation that was also more variable in height.

\section{Discussion}

Perennial buffer strips managed under UK agri-environment schemes on cultivated land are highly regulated with regards to permissible management actions and their timings. To receive payments, farmers and landowners are permitted to use only cutting to manage the swards and only after $15^{\text {th }}$ July. Such a standardised approach to managing the extensive buffer strip resource (approx. 30,000 ha in England) might therefore be contributing to the limited benefits of agri-environment schemes to farmland birds and other taxa (Kleijn et al., 2006; Baker et al., 2012). In the current study, we investigated novel techniques for the management of buffer strip habitats and explored the potential benefit of including forb species in seed mixes to enhance resource abundance for farmland birds. Plant and invertebrate resource values and their access to farmland birds were directly compared with 
the standard grass-only buffer strips that are managed with cutting. The importance of seed mix type and approaches to the management of the established sward have been demonstrated to be highly important in governing the resources provided, but also the potential for farmland birds to access them.

\subsection{Seed mix type}

Total PRI values in plots sown with the TG and FG seed mixes were $8.6 \%$ and $64.3 \%$ higher (respectively), compared to the grass-only plots. Inclusion of sown forb resources in the TG and FG plots is therefore likely to increase forage abundance (Holt et al., 2010) and consequently their overall use by farmland birds (Henderson et al., 2007). In contrast, the greater contribution of sown grass resources to total plant PRI values in GO plots might be expected to support more bird species that prefer carbohydrate-rich seed, including buntings (Perkins et al., 2007). The GO plots were also associated with greater resource values for unsown forbs and unsown grasses than plots sown with the other seed mixes, which would also enhance their value for farmland birds (Wilson et al., 1999). The unsown forbs consisted of 97 species across the three sites and included annuals (Stellaria media, Sinapis arvensis), biennials (Cirsium vulgare, Heracleum sphondylium) and perennial species (Cirsium arvense, Ranunculus repens, Rumex crispus), whilst of the 19 unsown grass species recorded, Poa annua, Poa trivialis, Agrostis stolonifera and Anisantha sterilis were the most abundant resource providers. It was previously determined that plots established with the grass-only seed mix were more susceptible to invasion by pernicious weeds (Westbury et al., 2008); these included C. vulgare, which is an important food source for goldfinches (Holland et al., 2006), and Galium aparine. However, they were also more likely to support Matricaria discoidea, a species described as a desirable weed (Marshall et al., 2003), although as with G. aparine, its direct value for farmland birds is limited (Holland et al., 2006). The greater presence of unsown species in the grass-only plots might be expected due to the lower plant species diversity enabling the establishment and colonisation of additional species (van Ruijven et al., 2003).

Despite the extra cost of sowing forb species, plots established with the grass-only seed mix were associated with similar values of total beetle abundance and beetle mass to plots sown with seed mixes containing forbs. Sward structure rather than plant species composition therefore had an important influence on beetle responses (Southwood et al., 1979). Differences in the relative contributions of phytophagous and predatory beetle species in buffer strips have been observed to differ according to seed mix type (Woodcock et al., 2008), which is important from a biodiversity rather than bird food perspective. 


\subsection{Buffer strip management}

The treatment of scarification was shown to enhance resource provision from unsown forbs and grasses across all seed mix types, but by doing so, reduced total values of plant resources, mainly due to a reduction in the relative abundance of sown forb resources. The treatment of scarification might therefore reduce the value of buffer strips containing sown forbs to farmland birds (e.g. sparrows and finches) that prefer oil-rich seeds (Perkins et al., 2007). Furthermore, the tendency for scarification to reduce beetle abundance in the GO and TG plots compared to cutting also demonstrates a negative aspect of this management treatment for farmland birds. However, when considering the trade-off between resource abundance and accessibility, it is evident that the treatment of scarification was instrumental in promoting access to the resources available in the buffer strips. Reduced sward heights, greater values of bare ground, and increased values for the coefficient of variation of sward height are all important indicators of sward accessibility (Whittingham and Devereux, 2008).

As with scarification, the graminicide treatment reduced the resource abundance of sown grasses, and also that of unsown grasses, but was associated with greater values of sown forb resources. Sward heights, values of bare ground, and values for the coefficient of variation of sward height were similar to cutting, indicating no enhanced access to resources, but not all seed-eating passerines are ground-foragers. For example, goldfinches will perch directly on vegetation to access flower-heads of black knapweed (Centaurea nigra) and teasel (Dipsacus fullonum) (D. Westbury, pers. observation). Such bird species are therefore more likely to respond to plant species composition rather than access, explaining the lack of difference in bird use between the treatments of scarification and graminicide (Henderson et al., 2007), despite differences in sward accessibility.

\subsection{Temporal change in resources}

Irrespective of management treatment, the overall decline of resources provided by the unsown grasses, unsown forbs, and sown grasses might be expected due a gradual reduction in productivity following cessation of fertilizer applications (Oomes, 1990), coupled with a general decline in the extent of bare ground available for the establishment of annual species (Westbury et al., 2008). However, the significant interactions between year and seed mix for values of total plant resources and sown forb resources illustrates that responses were not consistent. Values tended to increase in plots sown with the GO and FG seed mixes, in contrast to a decrease in plots sown with the TG mix. An increase with time of 
sown forbs in the GO plots is due to increased colonisation from neighbouring plots, particularly by Dipsacus fullonum and Leucanthemum vulgare, whilst the increase in plots sown with the FG seed mix is attributed to increased contributions from Lotus corniculatus, Plantago lanceolata, Centaurea nigra, Ranunculus acris and Rumex acetosa. The performance of some of these species has been recorded to increase with time elsewhere (Pywell et al., 2003), and are important in the diets of farmland birds (Wilson et al. 1999). The value of plots sown with the FG seed mix therefore appears to be increasing with time. In contrast, the overall decline in sown forb resources in plots sown with the TG mix can be explained by dramatic declines in $L$. vulgare abundance. This species is noted as being valuable for Cardueline finches (Wilson et al., 1999), but these plots also had increased contributions from $C$. nigra and $D$. fullonum, both of which are also important for finches (Wilson et al., 1999).

The significant interaction between year and management for values of unsown forb resources indicated that in 2004 the management treatments of cutting and graminicide were associated with lower resource values. This was driven by a decline in Cirsium arvense in plots treated with cutting, and a decline in Cirsium vulgare in plots treated with graminicide. Both thistle species provide an important seed resource for farmland birds (Holland et al., 2006), but are also classed as pernicious weeds (Westbury et al., 2008).

Interpreting time trends in beetle abundance is problematic as populations tend to fluctuate on a yearly basis (Collins et al., 2003), but it is evident they generally increased with time irrespective of management treatment, suggesting an increased value of the buffer strip plots for farmland birds.

\section{Conclusion}

This study has demonstrated the value of including forbs in seed mixes used to establish buffer strips by increasing plant resources for farmland birds, although this was not coupled with an increase in beetle abundance and mass. The study has shown that novel buffer strip management techniques can be used to strongly influence resource abundance and their access by farmland birds. It is evident that the standard approach of establishing buffer strips with grass-only seed mixes and managing with annual cutting has potential to provide plant and invertebrate resources for farmland birds, but access to these resources is restricted by tall homogenous swards and a limited amount of bare ground. In turn, this study has shown that the value of grass-only buffer strips for farmland birds can be enhanced through the use of scarification. Although scarification reduced plant resources in the buffer 
strips, it was highly effective at opening up the sward to increase access for farmland birds. However, buffer strips have a multifunctional role in agricultural landscapes, which includes the protection of water courses, and scarification adjacent to ditches and water courses might be deemed unsuitable. Therefore, as with current management guidelines for cutting grass-only buffer strips, we recommend that to enhance the value of existing buffer strips to farmland birds, scarification should be periodically applied to a narrow (1-3 m) strip next to the crop edge. Barriers to the implementation of scarification are unlikely as farmers typically have access to the cultivation equipment required.

\section{Acknowledgements}

The authors would like to thank Chris Brodie, Victoria Chapman, Andrew Edwards, Hannah Gibbons, Tracy Gray, Louisa Horton, Alex Morss, Martina Stranska, and Corin Wilkins for their help in the field. The SAFFIE project was sponsored by the Department for Environment, Food and Rural Affairs (Defra), the Scottish Executive Environment and Rural Affairs Department (SEERAD) and Natural England, through the Sustainable Arable LINK programme (LK 0926). Industrial sponsors were: British Potato Council, Agricultural Industries Confederation (AIC), Crop Protection Association, Home-Grown Cereals Authority (HGCA), Jonathan Tipples, Linking Environment And Farming (LEAF), Royal Society for the Protection of Birds (RSPB), Sainsbury's Supermarkets Ltd., Syngenta, National Trust, and Wm Morrison Supermarkets PLC.

\section{References}

Aschwanden, J., Holzgang, O., Jenni, L., 2007. Importance of ecological compensation areas for small mammals in intensively farmed areas. Wildlife Biol. 13, 150-158.

Atkinson, P.W., Fuller, R.J., Vickery, J.A., Conway, G.J., Tallowin, J.R.B., Smith, R.E.N., Haysom, K.A., Ings, T.C., Asteraki, E.J., Brown, V.K., 2005. Influence of agricultural management, sward structure and food resources on grassland field use by birds in lowland England. J. Appl. Ecol. 42, 932-942.

Baker, D.J., Freeman, S.N., Grice, P.V., Siriwardena, G.M., 2012. Landscape-scale responses of birds to agri-environment management: a test of the English Environmental Stewardship scheme. J. Appl. Ecol. 49, 871-882.

Biaggini, M., Corti, C., 2015. Reptile assemblages across agricultural landscapes: where does biodiversity hide? Anim. Biodivers. Conserv. 38, 163-174.

Bohac, J., 1999. Staphylinid beetles as bioindicators. Agric. Ecosyst. Environ. 74, 357-372.

Broughton, R.K., Shore, R.F., Heard, M.S., Amy, S.R., Meek, W.R., Redhead, J.W., Turk, A., Pywell, R.F., 2014. Agri-environment scheme enhances small mammal diversity and abundance at the farm-scale. Agric. Ecosyst. Environ. 192, 122-129. 
Buckingham, D.L., Peach, W.J., 2006. Leaving final-cut grass silage in situ overwinter as a seed resource for declining farmland birds. Biodivers. Conserv. 15, 3827-3845.

Burgess, M.D., Bright, J.A., Morris, A.J., Field, R.H., Grice, P.V., Cooke, A.I., Peach, W., 2015. Influence of agri-environment scheme options on territory settlement by Yellowhammer (Emberiza citronella) and Corn Bunting (Emberiza calandra). J. Ornithol. 156, 153-163.

Butler, S.J., Mattison, E.H.A., Glithero, N.J., Robinson, L.J., Atkinson, P.W., Gillings, S., Vickery, J.A., Norris, K., 2010. Resource availability and the persistence of seed-eating bird populations in agricultural landscapes : a mechanistic modelling approach. J. Appl. Ecol. 47, 67-75.

Collins, K.L., Boatman, N.D., Wilcox, A., Holland, J.M., 2003. A 5-year comparison of overwintering polyphagous predator densities within a beetle bank and two conventional hedgebanks. Ann. of Appl. Biol. 143, 63-71.

Critchley, C.N.R., Fowbert, J.A., Sherwood, A.J., Pywell, R.F., 2006. Vegetation development of sown grass margins in arable fields under a countrywide agrienvironment scheme. Biol. Conserv. 132, 1-11.

Donald, P.F., Green, R.E., Heath, M.F., 2001. Agricultural intensification and the collapse of Europe's farmland bird populations. Proc. R. Soc. Lond. Ser. B-Biol. Sci. 268, 25-29.

Douglas, D.J.T., Vickery, J.A., Benton, T.G., 2009. Improving the value of field margins as foraging habitat for farmland birds. J. Appl. Ecol. 46, 353-362.

Field, R.G., Gardiner, T., Mason, C.F., Hill, J., 2005. Agri-environment schemes and butterflies: the utilisation of 6 m grass margins. Biodivers. Conserv. 14, 1969-1976.

Fuller, R.J., Gregory, R.D., Gibbons, D.W., Marchant, J.H., Wilson, J.D., Baillie, S.R., Carter, N., 1995. Population declines and range contractions among lowland farmland birds in Britain. Conserv. Biol. 9, 1425-1441.

Henderson, I.G., Morris, A.J., Westbury, D.B., Woodcock, B.A., Potts, S.G., Ramsay, A.J., Coombes, R., 2007. Effects of field margin management on bird distributions around cereal fields. Aspects Appl. Biol. 81, 53-60.

Holland, J.M., Hutchison, M.A.S., Smith, B., Aebischer, N.J., 2006. A review of invertebrates and seed-bearing plants as food for farmland birds in Europe. Ann. Appl. Biol. 148, 4971.

Holt, C.A., Atkinson, P.W., Vickery, J.A., Fuller, R.J., 2010. Do field margin characteristics influence songbird nest-site selection in adjacent hedgerows? Bird Stud. 57, 392-395.

Kleijn, D., Baquero, R.A., Clough, Y., Diaz, M., De Esteban, J., Fernandez, F., Gabriel, D., Herzog, F., Holzschuh, A., Johl, R., Knop, E., Kruess, A., Marshall, E.J.P., SteffanDewenter, I., Tscharntke, T., Verhulst, J., West, T.M., Yela, J.L., 2006. Mixed biodiversity benefits of agri-environment schemes in five European countries. Ecol. Lett. 9, 243-254.

Marshall, E.J.P., Brown, V.K., Boatman, N.D., Lutman, P.L., 2003. The role of weeds in supporting biological diversity within crop fields. Weed Res. 43, 77-89. 
Merckx, T., Feber, R.E., Dulieu, R.L., Townsend, M.C., Parsons, M.S., Bourn, N.A.D., Riordan, P., MacDonald, D.W., 2009. Effect of field margins on moths depends on species mobility: Field-based evidence for landscape-scale conservation. Agric. Ecosyst. Environ. 129, 302-309.

Oomes, M.J.M., 1990. Changes in dry matter and nutrient yields during the restoration of species-rich grasslands. J. Veg. Sci. 1, 333-338.

Peach, W.J., Denny, M., Cotton, P.A., Hill, I.F., Gruar, D., Barritt, D., Impey, A., Mallord, J., 2004. Habitat selection by song thrushes in stable and declining farmland populations. J. Appl. Ecol. 41, 275-293.

Peach, W.J., Lovett, L.J., Wotton, S.R., Jeffs, C., 2001. Countryside stewardship delivers cirl buntings (Emberiza cirlus) in Devon, UK. Biol. Conserv. 101, 361-373.

Perkins, A.J., Anderson, G., Wilson, J.D., 2007. Seed food preferences of granivorous farmland passerines. Bird Stud. 54, 46-53.

Pywell, R.F., Bullock, J.M., Roy, D.B., Warman, L., Walker, K.J., Rothery, P., 2003. Plant traits as predictors of performance in ecological restoration. J. Appl. Ecol. 40, 65-77.

Rogers, L.E., Hinds, W.T., Buschbom, R.L., 1976. General weight vs length relationship for insects. Ann. Entomol. Soc. Am. 69, 387-389.

Saint-Germain, M., C. M. Buddle, M. Larrivee, A. Mercado, T. Motchula, E. Reichert, T. E. Sackett, Z. Sylvain, and A. Webb. 2007. Should biomass be considered more frequently as a currency in terrestrial arthropod community analyses? J. Appl. Ecol. 44, 330-339.

Schabenberger, O., Pierce, F.J., 2002. Contemporary Statistical Models for the Plant and Soil Sciences. CRC Press, London, UK.

Southwood, T.R.E., Brown, V.K., Reader, P.M., 1979. Relationships of plant and insect diversities in succession. Biol. J. Linn. Soc. 12, 327-348.

Stace, C., 2010. New Flora of the British Isles. Cambridge University Press, Cambridge, UK.

Stewart, K.E.J., Bourn, N.A.D., Thomas, J.A., 2001. An evaluation of three quick methods commonly used to assess sward height in ecology. J. Appl. Ecol. 38, 1148-1154.

van Ruijven, J., De Deyn, G.B., Berendse, F., 2003. Diversity reduces invasibility in experimental plant communities: the role of plant species. Ecol. Lett. 6, 910-918.

Vickery, J.A., Fuller, R.J., 1998. Use of cereal fields by birds: A review in relation to field margin managements. British Trust for Ornithology Research Report No. 195, p. 118.

Vickery, J.A., Bradbury, R.B., Henderson, I.G., Eaton, M.A., Grice, P.V., 2004. The role of agri-environment schemes and farm management practices in reversing the decline of farmland birds in England. Biol. Conserv. 119, 19-39.

Vickery, J.A., Feber, R.E., Fuller, R.J., 2009. Arable field margins managed for biodiversity conservation: A review of food resource provision for farmland birds. Agric. Ecosyst. Environ. 133, 1-13. 
Vickery, J.A., Tallowin, J.R., Feber, R.E., Asteraki, E.J., Atkinson, P.W., Fuller, R.J., Brown, V.K., 2001. The management of lowland neutral grasslands in Britain: effects of agricultural practices on birds and their food resources. J. Appl. Ecol. 38, 647-664.

Westbury, D.B., Dunnett, N.P., 2008. The promotion of grassland forb abundance: A chemical or biological solution? Basic Appl. Ecol. 9, 653-662.

Westbury, D.B., Woodcock, B.A., Harris, S.J., Brown, V.K., Potts, S.G., 2008. The effects of seed mix and management on the abundance of desirable and pernicious unsown species in arable buffer strip communities. Weed Res. 48, 113-123.

Westbury, D.B., Mortimer, S.R., Brook, A.J., Harris, S.J., Kessock-Philip, R., Edwards, A.R., Chaney, K., Lewis, P., Dodd, S., Buckingham, D.L., Peach, W.J., 2011. Plant and invertebrate resources for farmland birds in pastoral landscapes. Agriculture Ecosystems \& Environment 142, 266-274.

Whittingham, M.J., Devereux, C.L., 2008. Changing grass height alters foraging site selection by wintering farmland birds. Basic Appl. Ecol. 9, 779-788.

Wilson, J.D., Arroyo, B.E., Clark, S.C., 1996. Diet of Bird Species of Lowland Farmland: a Literature Review. Unpubl. Rep. to Department of the Environment and Joint Nature Conservation Committee. University of Oxford, Royal Society for the Protection of Birds, UK.

Wilson, J.D., 2001. Weeds as a food resource for farmland birds: What, where and how many should we leave? BCPC conference - Weeds. British Crop Protection Council, 49 Downing Street, Farnham, Surrey, GU9 7PH, UK, Brighton, UK, pp. 391-398.

Wilson, J.D., Morris, A.J., Arroyo, B.E., Clark, S.C., Bradbury, R.B., 1999. A review of the abundance and diversity of invertebrate and plant foods of granivorous birds in northern Europe in relation to agricultural change. Agric. Ecosyst. Environ. 75, 13-30.

Winspear, R., Grice, P.V., Peach, W.J., Phillips, J., Aebischer, N.J., Thompson, P.G.L., Egan, J. \& Nowakowski, M. 2010. The development of farmland bird packages for arable farmers in England. Ann. Appl. Biol. 100: 347-352.

Woodcock, B.A., Potts, S.G., Tscheulin, T., Pilgrim, E., Ramsey, A.J., Harrison-Cripps, J., Brown, V.K., Tallowin, J.R., 2009. Responses of invertebrate trophic level, feeding guild and body size to the management of improved grassland field margins. J. Appl. Ecol. 46, 920-929.

Woodcock, B.A., Pywell, R.F., 2010. Effects of vegetation structure and floristic diversity on detritivore, herbivore and predatory invertebrates within calcareous grasslands. Biodivers. Conserv. 19, 81-95.

Woodcock, B.A., Westbury, D.B., Potts, S.G., Harris, S.J., Brown, V.K., 2005. Establishing field margins to promote beetle conservation in arable farms. Agric. Ecosyst. Environ. 107, 255-266.

Woodcock, B.A., Westbury, D.B., Tscheulin, T., Harrison-Cripps, J., Harris, S.J., Ramsey, A.J., Brown, V.K., Potts, S.G., 2008. Effects of seed mixture and management on beetle assemblages of arable field margins. Agriculture Ecosystems \& Environment 125, 246-254. 
Tables

Table 1. Responses of the different plant resource categories according to seed mix type, management treatment and year.

\begin{tabular}{lcccccc}
\hline Category & Seed mix & Management & Year & $\begin{array}{c}\text { Year } \mathbf{x} \\
\text { Seed mix }\end{array}$ & $\begin{array}{c}\text { Year } \mathbf{x} \\
\text { Management }\end{array}$ & $\begin{array}{c}\text { Seed mix } \mathbf{x} \\
\text { Management }\end{array}$ \\
\hline Total Resource & $\mathrm{F}_{2,380}=43.0^{\star \star \star}$ & $\mathrm{F}_{2,380}=20.3^{\star \star \star}$ & $\mathrm{F}_{2,380}=42.0^{\star \star \star}$ & $\mathrm{F}_{4,380}=3.5^{\star \star}$ & $\mathrm{ns}$ & $\mathrm{ns}$ \\
Forbs -Sown & $\mathrm{F}_{2,376}=665.4^{\star \star \star}$ & $\mathrm{F}_{2,376}=32.1^{\star \star \star}$ & $\mathrm{F}_{2,376}=3.5^{\star}$ & $\mathrm{F}_{4,376}=4.0^{\star \star}$ & $\mathrm{ns}$ & $\mathrm{F}_{4,376}=8.5^{\star \star \star}$ \\
Forbs -Unsown & $\mathrm{F}_{2,380}=18.3^{\star \star \star}$ & $\mathrm{F}_{2,380}=29.0^{\star \star \star}$ & $\mathrm{F}_{2,380}=9.2^{\star \star \star}$ & $\mathrm{ns}$ & $\mathrm{F}_{4,380}=4.9^{\star \star \star}$ & $\mathrm{ns}$ \\
Grasses -Sown & $\mathrm{F}_{2,380}=9.0^{\star \star \star}$ & $\mathrm{F}_{2,380}=32.3^{\star \star \star}$ & $\mathrm{F}_{2,380}=61.1^{\star \star \star}$ & $\mathrm{ns}$ & $\mathrm{ns}$ & $\mathrm{F}_{2,380}=9.5^{\star \star \star}$ \\
Grasses -Unsown & $\mathrm{F}_{2,384}=10.2^{\star \star \star}$ & $\mathrm{F}_{2,384}=23.7^{\star \star \star}$ & $\mathrm{F}_{2,384}=24.5^{\star \star \star}$ & $\mathrm{ns}$ & $\mathrm{ns}$ & $\mathrm{ns}$
\end{tabular}

ns $=$ non-significant at $P>0.05,{ }^{\star} P<0.05,{ }^{*} P<0.01,{ }^{*} * *<0.001$

Table 2. The influence of seed mix type, management treatment and year on total beetle abundance and mass.

\begin{tabular}{lcccc}
\hline Category & Seed mix & Management & Year & $\begin{array}{c}\text { Year } \mathbf{x} \\
\text { Management }\end{array}$ \\
\hline Beetle Abundance & $\mathrm{F}_{2,380}=3.0^{\star}$ & $\mathrm{ns}$ & $\mathrm{F}_{2,380}=78.4^{\star \star \star}$ & $\mathrm{F}_{4,380}=2.8^{\star}$ \\
Beetle Mass & $\mathrm{F}_{2,386}=3.4^{\star}$ & $\mathrm{ns}$ & $\mathrm{F}_{2,386}=48.6^{\star \star \star}$ & $\mathrm{ns}$ \\
\hline
\end{tabular}

ns $=$ non-significant at $P>0.05,{ }^{\star} P<0.05,{ }^{\star \star} P<0.01,{ }^{\star \star \star} P<0.001$

Table 3. The influence of seed mix type, management treatment and year on sward attributes ( $\mathrm{CV}=$ coefficient of variation).

\begin{tabular}{lcccc}
\hline Category & Seed mix & Management & Year & $\begin{array}{c}\text { Seed mix } x \\
\text { Management }\end{array}$ \\
\hline Sward Height & $F_{2,380}=5.0^{\star \star}$ & $F_{2,380}=46.3^{\star \star \star}$ & $F_{2,380}=6.0^{\star \star}$ & $F_{4,380}=3.8^{\star \star}$ \\
CV. Sward Height & ns & $F_{2,386}=6.8^{\star \star \star}$ & $F_{2,886}=6.1^{\star \star}$ & ns \\
Bare Ground & ns & $F_{2,398}=29.8^{\star \star \star}$ & $F_{2,398}=4.3^{\star \star}$ & ns
\end{tabular}

ns $=$ non-significant at $P>0.05,{ }^{\star} P<0.05,{ }^{\star \star} P<0.01,{ }^{\star \star \star} P<0.001$ 
Figures

a) Total plant resources

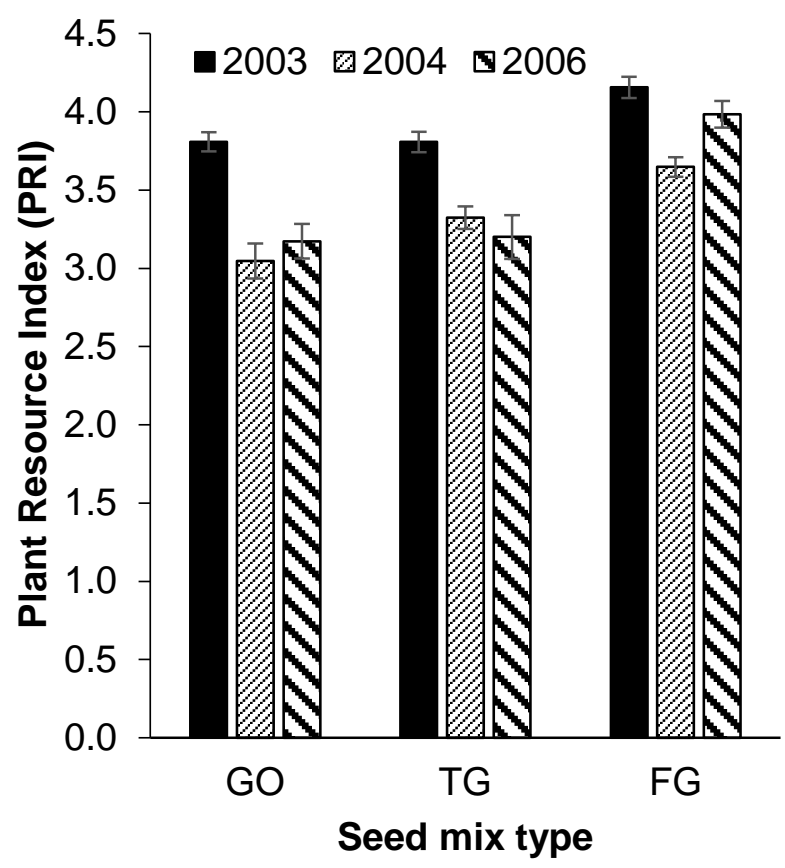

c) Sown forb resources

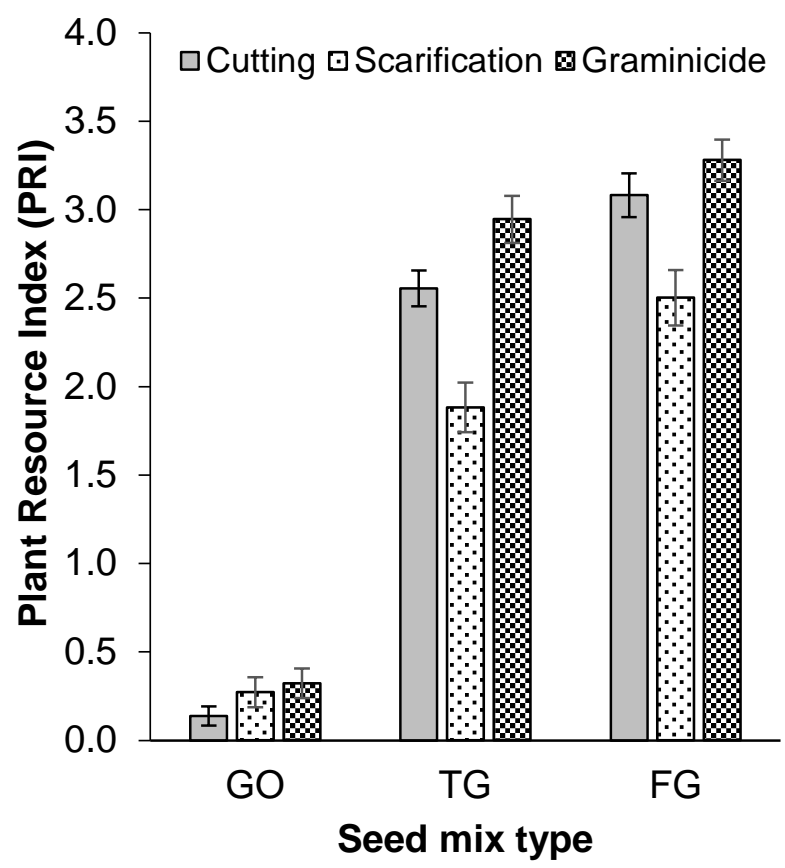

b) Sown forb resources

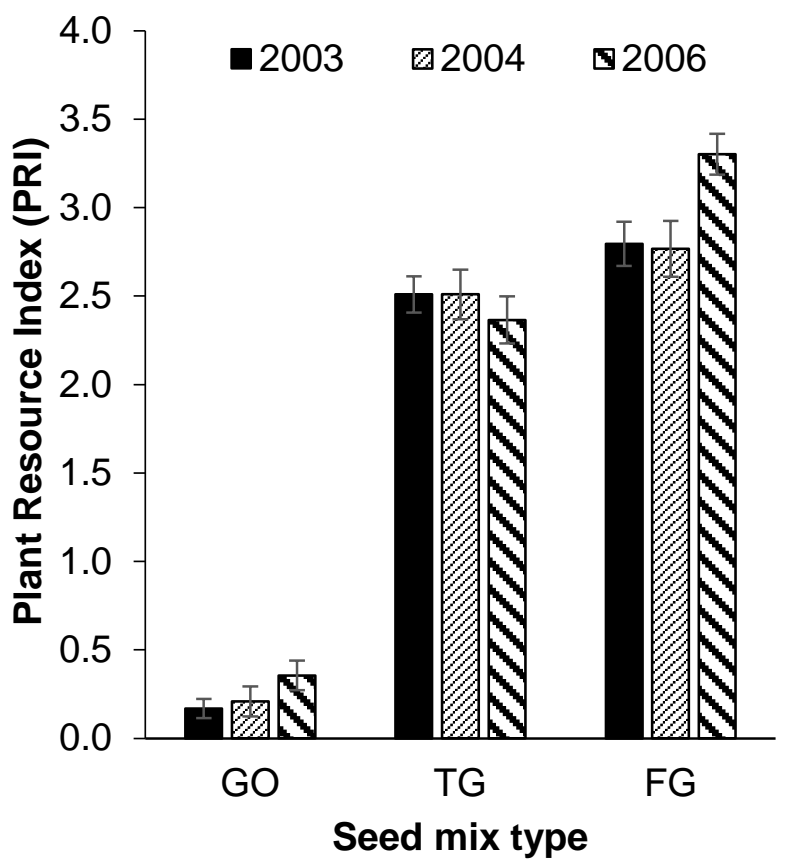

d) Sown grass resources

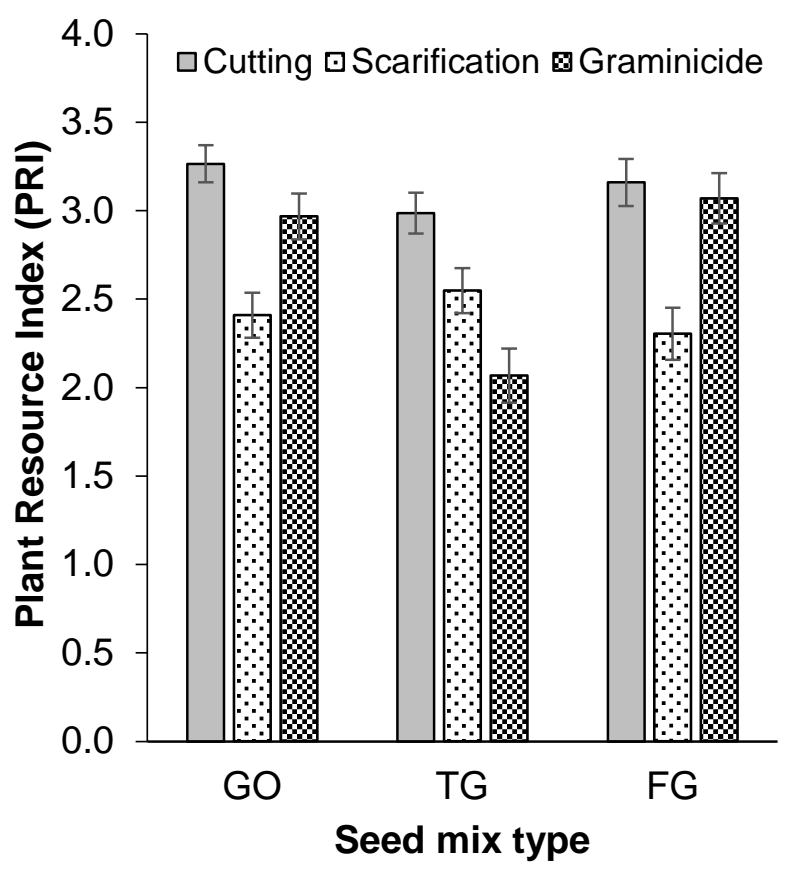

Figure 1. Mean PRI values of a) total plant resources ( \pm SE) (log transformed), and b) sown forb plant resources $( \pm S E)$ (log +1 transformed), according to seed mix type and year, and $c)$ sown forb plant resources $( \pm S E)$ (log +1 transformed) and d) sown grass plant resources $( \pm S E)$ 
(log+1 transformed), according to management treatment and seed mix type. $\mathrm{GO}=$ Grass Only seed mix, TG = Tussock Grass and forb mix, FG = Fine Grass and forb mix.

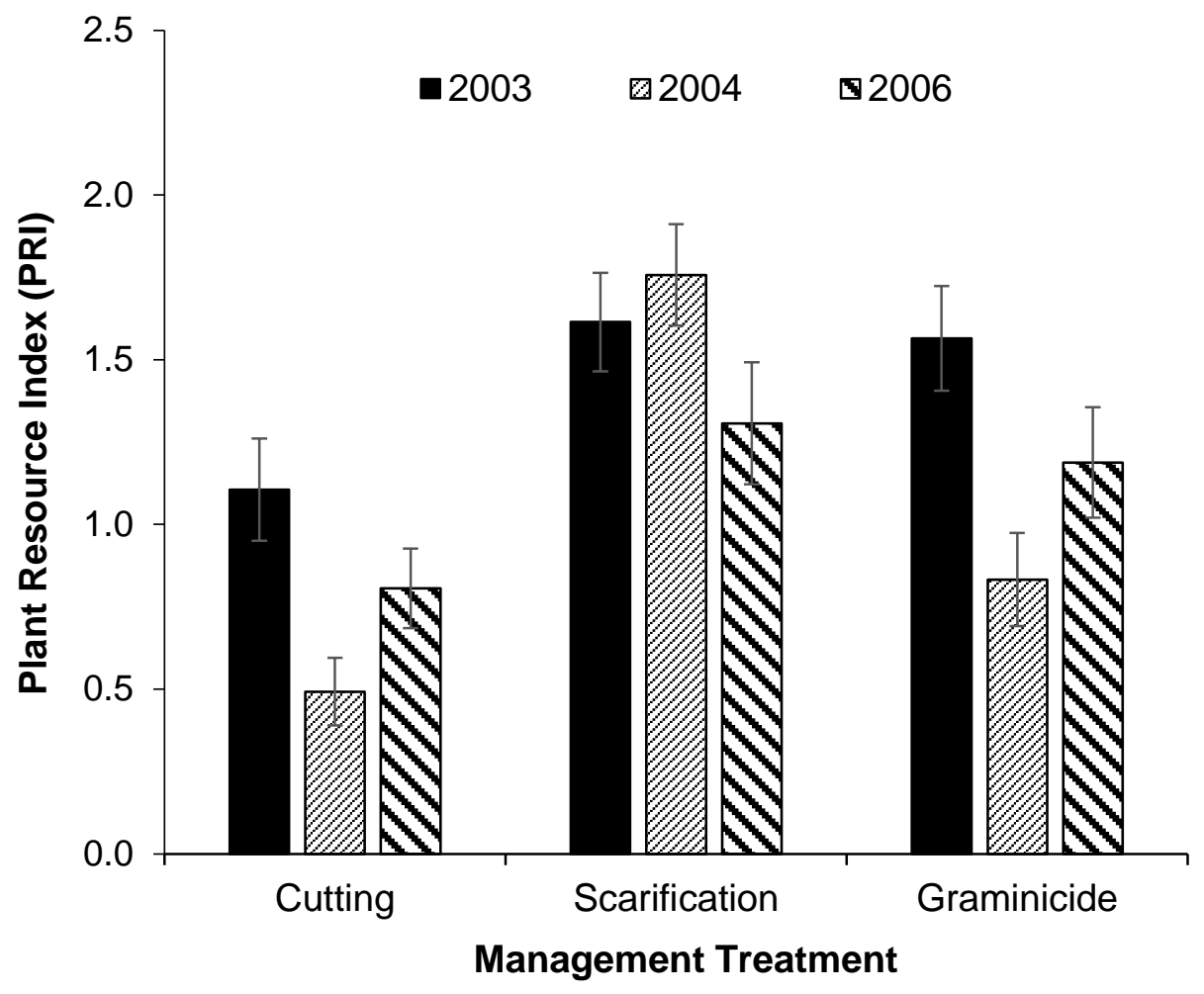

Figure 2. Mean (log+1 transformed) PRI values of unsown forb plant resources $( \pm \mathrm{SE})$ according to management treatment and year. 


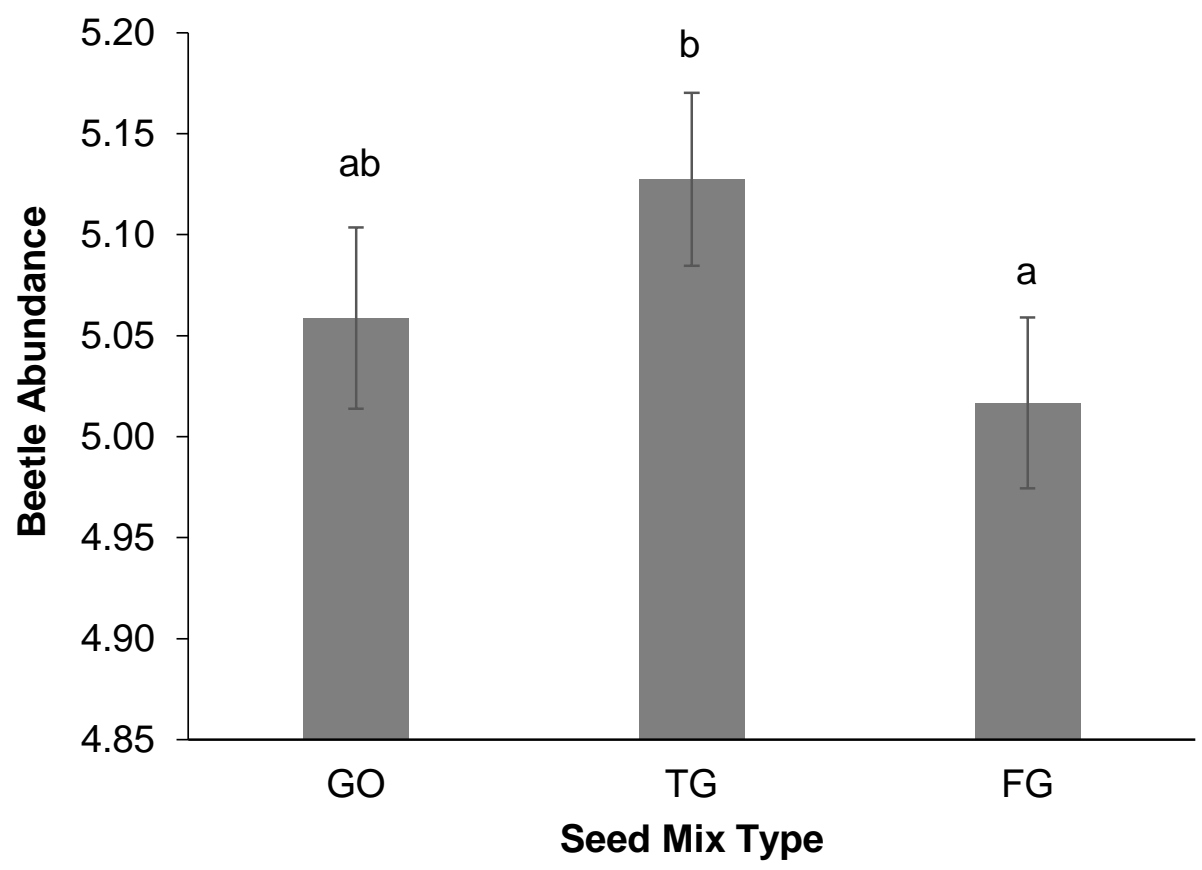

Figure 3. Mean (log transformed) values of total beetle abundance $( \pm S E)$ according to seed mix type. Bars with the same letter do not differ significantly $(P>0.05)$.

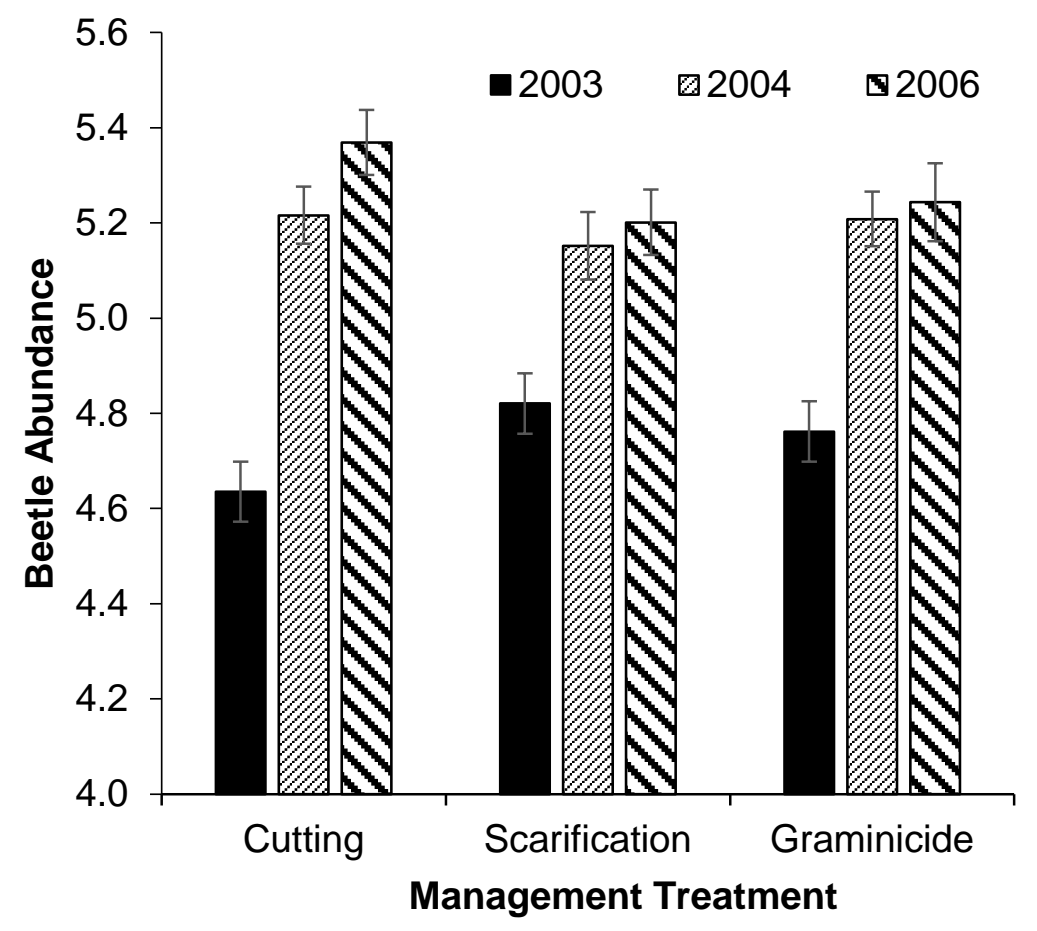

Figure 4. Mean (log transformed) values of total beetle abundance ( \pm SE) according to management treatment and year. 


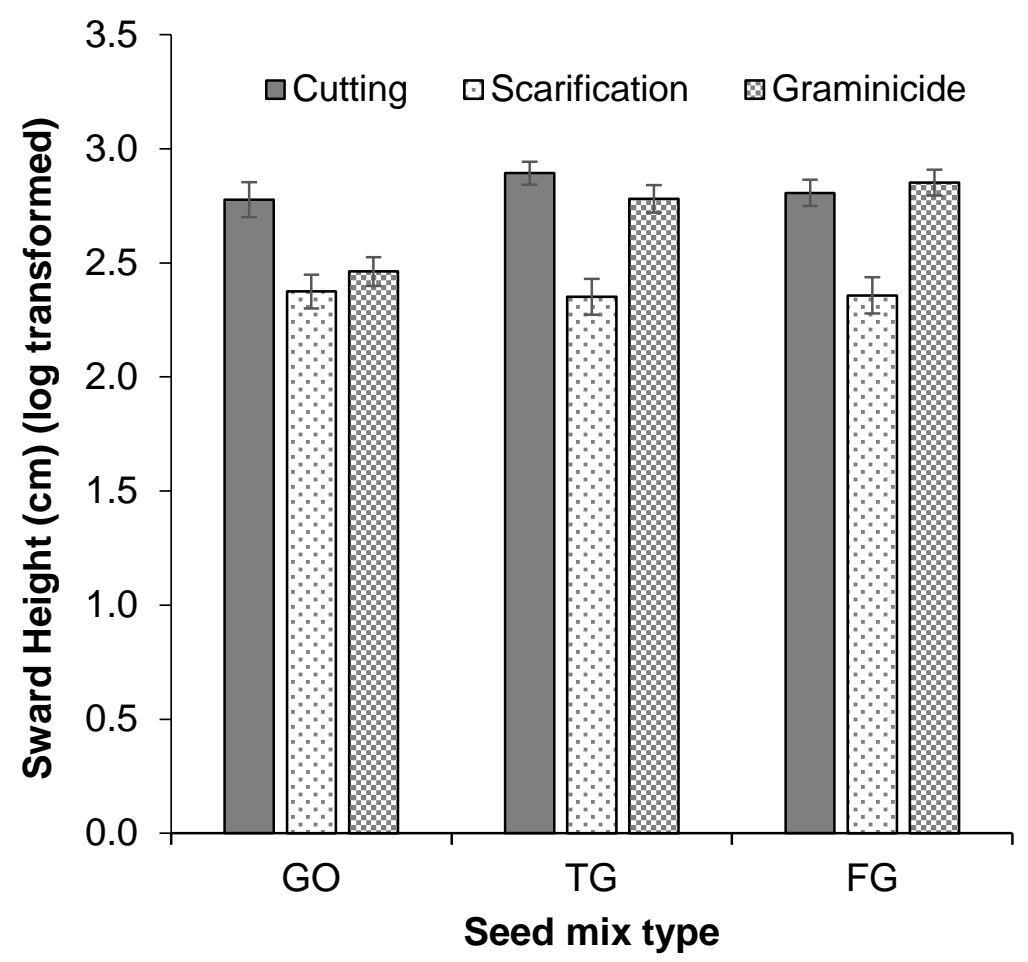

Figure 5. Mean ( \pm SE) sward height (cm) (log transformed) according to management treatment and seed mix type.

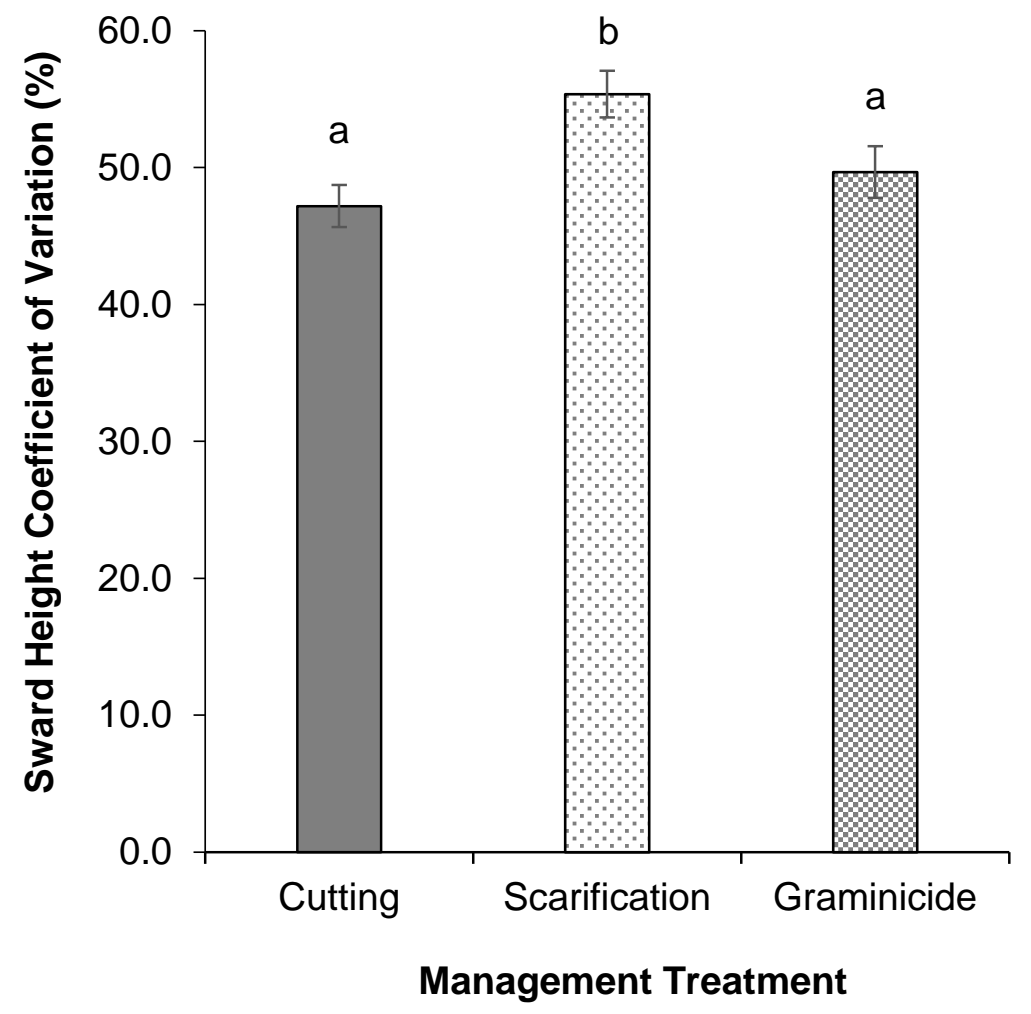


Figure 6. Mean ( \pm SE) values of coefficient of variation (\%) of sward height according to management treatment. Bars with the same letter do not differ significantly $(P>0.05)$.

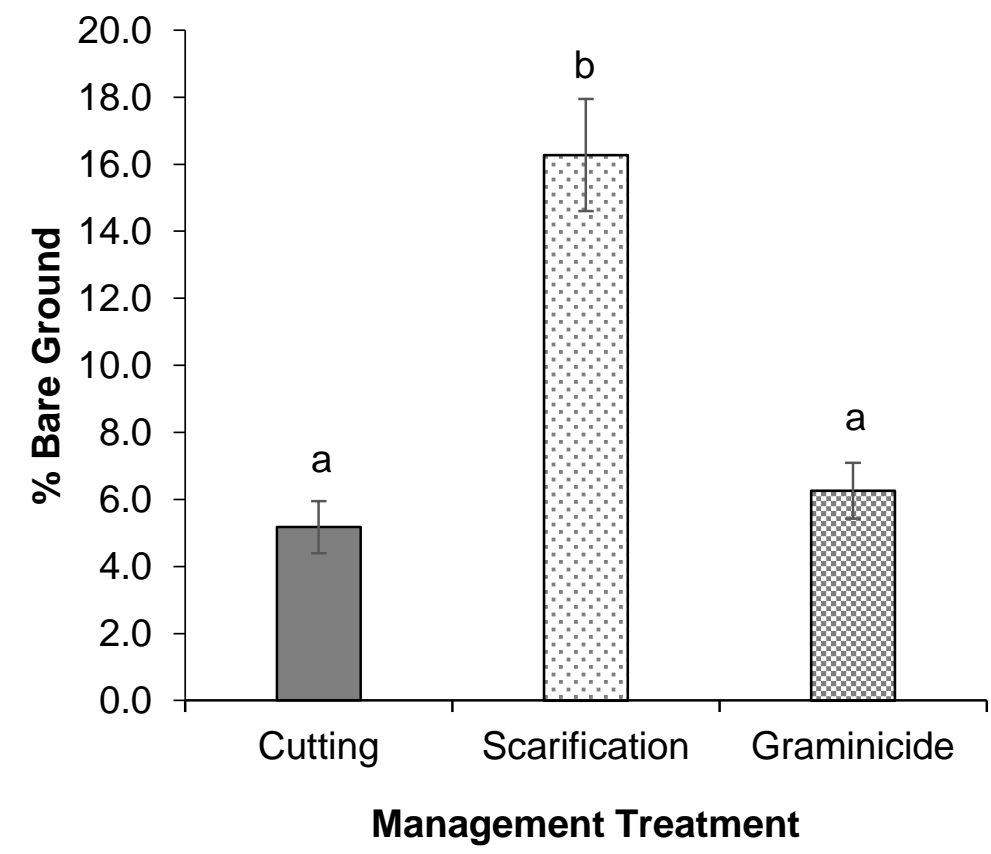

Figure 7. Mean ( \pm SE) values of bare ground (\%) according to management treatment. Original values presented but statistical analysis was performed on log transformed data $(L N+1)$. Bars with the same letter do not differ significantly $(P>0.05)$. 


\section{Appendix}

Table 1. Composition of the seed mixtures used to establish the three buffer strip types. The fine grass and forb mix was tailored according to site. When a species was sown at a particular site (or sites), the site is indicated by a letter(s) in parentheses: B =Boxworth; $\mathrm{G}=$ Gleadthorpe; $\mathrm{HM}=$ High Mowthorpe.

\begin{tabular}{|c|c|c|c|}
\hline & Grass-only mix (GO) & $\begin{array}{l}\text { Tussock grass and } \\
\text { forbs (TG) }\end{array}$ & $\begin{array}{l}\text { Fine grass and forbs } \\
\text { (FG) }\end{array}$ \\
\hline Grasses & $\begin{array}{l}\text { Agrostis capillaris } \\
\text { Cynosurus cristatus } \\
\text { Dactylis glomerata } \\
\text { Festuca pratensis } \\
\text { Festuca ovina } \\
\text { Festuca rubra } \\
\text { Poa pratensis }\end{array}$ & $\begin{array}{l}\text { Alopecurus pratensis } \\
\text { Dactylis glomerata } \\
\text { Deschampsia caespitosa } \\
\text { Festuca pratensis } \\
\text { Festuca rubra } \\
\text { Holcus lanatus } \\
\text { Phleum pratense }\end{array}$ & $\begin{array}{l}\text { Agrostis capillaris } \\
\text { Cynosurus cristatus } \\
\text { Festuca rubra }\end{array}$ \\
\hline Forbs & None & $\begin{array}{l}\text { Achillea millefolium } \\
\text { Centaurea nigra } \\
\text { Centaurea scabiosa } \\
\text { Daucus carota } \\
\text { Dipsacus fullonum } \\
\text { Galium mollugo } \\
\text { Geranium pratense } \\
\text { Lathyrus pratensis } \\
\text { Leucanthemum vulgare } \\
\text { Silene dioica } \\
\text { Vicia cracca }\end{array}$ & 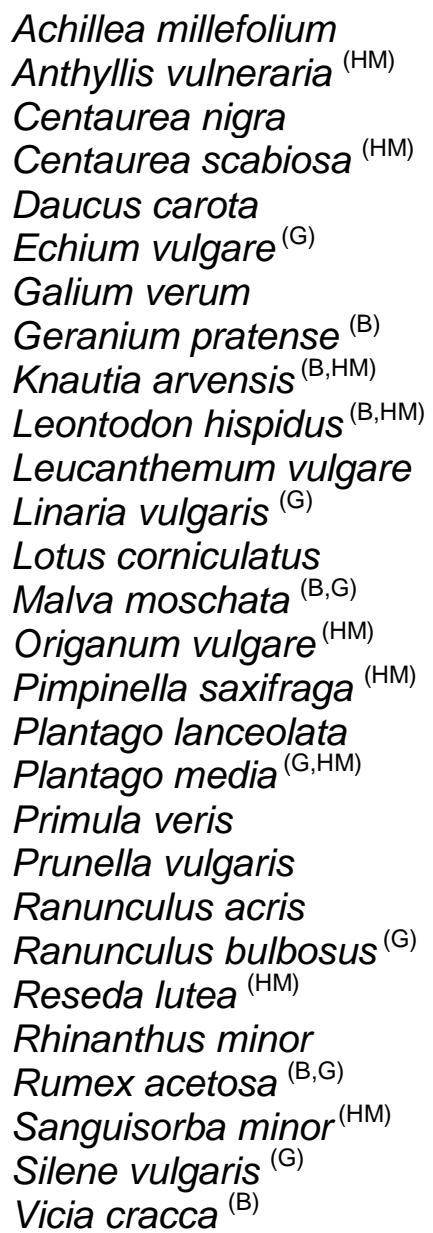 \\
\hline
\end{tabular}

